\title{
Gn 1,1-3,24 e a Teologia do Corpo
}

\author{
Orientador: Prof. Leonardo Agostini Fernandes \\ Pesquisadora: Suzana Regina Moreira \\ Fonte: $\mathrm{CNPq}$
}

\section{Introdução}

Esta pesquisa busca aprofundar a visão integral do ser humano, a partir dos relatos da criação contidos no livro do Gênesis, utilizando na abordagem comentários exegéticos, os comentários dos Padres da Igreja e do Magistério. Busca-se, com isso, compreender o embasamento bíblico-teológico dos ensinamentos de João Paulo II sobre a Teologia do Corpo.

A integralidade humana é refletida desde os princípios da fé judaico-cristã até os dias de hoje. É um tópico pertinente e importante a todos, pois fala diretamente à essência de nossa criação. O Magistério de João Paulo II também contém este enfoque; seus ensinamentos sobre a Teologia do Corpo resgatam o reconhecimento da beleza do corpo e da sexualidade, demonstrando que ambos são intrínsecos à integralidade humana. Desta forma, João Paulo II ressalta o significado do ser humano inserido no plano divino.

\section{Objetivos}

Resgatar a compreensão da dignidade e integralidade do ser humano, enquanto ser criado à imagem e semelhança de Deus, é o principal objetivo desta pesquisa. A partir deste, os objetivos particulares, são: a) Abordar os principais pontos exegéticos dos textos bíblicos sobre a criação e a queda do ser humano; b) Expor a compreensão destes textos bíblicos a partir da Tradição, em particular de alguns Padres da Igreja; c) Pontuar a compreensão antropológica do ser humano a partir do Magistério da Igreja; d) Apresentar os aspectos principais dos ensinamentos de João Paulo II sobre a Teologia do Corpo. 